\title{
$[3]$
}

\section{The Field Site}

To my knowledge no one has attempted an ethnography of all of the aesthetics of a community. Although the task may appear formidable, it seems an obvious exercise from which to begin building genuinely anthropological theories of aesthetics. But to be truly valuable such a study must at least attempt to be exhaustive, to document the profound and the trivial, the rare and the commonplace. It must not be limited by conventional notions of art and beauty or by traditional fieldwork practices. It must cast its net as widely and as dispassionately as possible. These aspirations made the selection of a field site a particularly demanding first exercise.

For a new kind of fieldwork, it is tempting to argue, one place is as good as another. In a general sense this is true, and I hope this study is the first of many such ethnographies. However, for an initial field trial I wished to limit obvious difficulties in order to make the task manageable. To this end I sought a community that was small, well-established, relatively isolated, and newly undergoing change through an influx of outsiders.

I looked for a small community so that I could get to know most, if not all, of the people in it and have a reasonable chance of documenting all of their aesthetic forms and activities. In the course of a year I hoped to participate in the full gamut of the activities of young and old, men and women, and to record and photograph aesthetic forms in as much detail as possible. A community of three hundred to five hundred inhabitants seemed ideal for these purposes.

It was also important to me that the community had been settled long enough for a range of social, political, religious, and economic networks to have established themselves. In such a community aes- 
thetic forms could be observed in a variety of settings and circumstances, ensuring that the question of what aesthetic forms do would not be unduly limited by the absence of particular social institutions. At the other extreme, however, I did not wish to investigate a community too rigorously defined by a limited set of externally imposed criteria, such as political or postal districts, lest these boundaries and the agents that had created them obscure the aesthetic. Ideally, then, the community would be old and defined in terms of local categories.

Relative isolation was important to control to some extent the factors influencing aesthetics and aesthetic choices. The perfect world of the controlled laboratory experiment is not replicable in the ethnographic realm, and any attempt to emulate it is likely to fail. No community is immune from outside influences or so isolated that external forces are trivial in comparison with internal ones. But relative isolation does give the fieldworker a fighting chance of separating the two and estimating their separate effects.

The final consideration, a new influx of outsiders, was predicated on an assumption, to be tested fully in the field, that such a transition might bring traditional values into sharp focus as one of the community's defenses. Social networks and relationships that might otherwise be only latent would become more easily accessible, and such hypothetical functions of aesthetics as markers for group and individual identity, facilitators and inhibitors of social interactions, cues for appropriate behavior, and so forth, would be more easily recognizable. The nature and functions of community bonds, in sum, may be examined more easily when they are in use. Should aesthetic forms play a role here, as one might reasonably expect without necessarily comprehending the mechanisms involved, the role may be readily analyzed.

Preliminary research indicated that the coastal region of North Carolina was a suitable area in which to find a field site. Most of this region has been settled since the colonial era, it is made up primarily of small, white, rural townships, and until recently many populations were isolated by sea, swamps, and sounds. In latter years, however, a modern road system was constructed, and tourists now flood the area from spring to fall.

After two tours of the area, I chose central "Marsh County" in North Carolina as the best site. Nucleated settlements here are small yet have a variety of social networks, and there are few if any rigid town boundaries. Tidewater, the focal community in this study, is bureaucratically divided in different ways-postal, voting, school districts- 
each division running athwart the others with none of the boundaries even closely coterminous with social or geographic ones.

The county was granted a charter at the end of the seventeenth century and, while this date does not provide a firm index of Tidewater's settlement, it is well documented that there has been a relatively large, stable population in the general neighborhood of the town for at least one hundred and fifty years. Until the 1930s the area was accessible by boat only, because it is surrounded by water and swamp. Since then bigger and better roads have established permanent links with outside towns and cities, and in the last two decades tourists have begun to invade the area in search of sun and sport. There is also a steady flow of migrants from Virginia seeking the area's lower cost of living while still commuting to the industrial parts of Virginia.

I believe, in retrospect, that the circumstances of my settling into the community were vital to the success of my fieldwork. Some consideration of those circumstances helps explain my choice of field techniques and my confidence in the general validity of my data.

It was important for me and the people of Tidewater that I am not an American-I was raised in Australia by parents of British birth and went to college in England. Thus I did not come to the community with the common American stereotypes concerning the rural South and in many ways was able to see and experience my surroundings with a fresh eye. Also, the people of Tidewater did not treat me as they would a slicker, a Yankee, or some other stereotyped American visitor but quite correctly assumed that how they lived was to me unusual but of interest and should be explained in detail. That is, they did not suspect me of harboring prejudices about their way of living, as American visitors often do, and against which they shield themselves in various ways.

I settled into what had once been a well-known boarding house but now was scarcely used as such because the widowed owner (whom I here call Florence) was becoming increasingly infirm. I was told I could stay for two weeks; then a decision as to my long-range accommodations would be made. Thus the community and I had a probationary period to adjust to each other, with an escape clause for both parties.

The day after my arrival was a Sunday, so I attended morning services at the local Baptist church. As I had scarcely been in the community twelve hours, it was something of a shock to hear the preacher mention my name during morning announcements and give a brief account of my mission. He, and a good number of the congrega- 
tion, had been apprised by Florence of my coming during Sunday school in the previous hour. On Monday morning Florence sent me off with a list of names of people it would be useful to know, people who had either been in church on Sunday or been called on the telephone to be put in the picture.

I did not make a deliberate effort during the first weeks of my stay in Tidewater to be "accepted," but the events of that time coupled with aspects of my own personality made the two-week deadline pass without notice or comment. Perhaps because of a Protestant upbringing I take pleasure in helping other people with household tasks, and I found it quite natural to assist with yardwork and the like around the house where I was living. In the first week of my stay, for example, I came home in the early afternoon to discover Florence and her daughter sizing up a limb that had sheared from a tree in a recent storm. Without demur they accepted my offer to cut it down. Also, since I spent a good deal of time going from house to house, it was easy for me to run errands or take messages in the process. It was not long before I was integrated into the daily workings of the house, treated more as a family member than as a lodger. I ate with the family, worked on projects with them, discussed personal affairs with them, and in the end formed lasting friendships with them.

Florence and her daughter were more responsible for my establishment in the community than I was through my own efforts. She made many decisions on whom I was to meet and when, and on how I should comport myself. When I arrived in the community, for example, I did not know how to drive a car. Florence considered this state of affairs intolerable, gave me a manual for the written test, and advised me that in a week we were going down to the county courthouse to get me a learner's permit. Thereafter she regularly took me out for lessons, which we sometimes combined with shopping expeditions or opportunities for visiting.

Whenever it was within her power Florence ingratiated me into social groups that it would have been inconceivable for me to get involved with on my own. She belonged to a bridge club of eight women who met in one another's houses in turn. When it came her turn to host them, she asked me to take her seat for her, claiming she was not up to playing. From that day on I was a member of the club.

A great deal of my fieldwork methodology I had to invent as the study progressed, although participant observation was the essential ingredient. I attempted a blanket photographic documentation of all visual aesthetics, ranging through house interiors and exteriors, cloth- 
ing, automobiles, decoys, quilts, and so on. I participated in work, religious, and leisure activities such as fishing, farming, guiding, hymn singing, storytelling, hunting, card playing, and television watching, using a camera and portable tape recorder whenever they were unobtrusive.

I considered formal methods of elicitation but rejected most of them because of the nature of my relationships to the community and the particular needs of my investigation. I rejected out of hand formal questionnaires and formal experimental testing as essentially destructive to the relationships I had established and as unlikely to reveal the kind of information I was seeking. During my first tours of the area I had watched an anthropologist use a questionnaire as part of a government survey. Although the responses of the local people were obviously meant to be sincere, the questionnaire created a clear barrier: before and after the question period relations were relaxed and cordial, but during it they were strained and artificial. I saw no value in creating uncomfortable situations, particularly as I had little reason to suppose the results would be of any significance for what I sought. My goal was to understand the aesthetic realm in normal life, not to create unnatural situations.

Perhaps the most important reason for eschewing formal methods concerned the community's posture toward outsiders. Tidewater has had to come to terms in recent years with a flood of newcomers whose full effects will be made explicit in later chapters. From the standpoint of methodology certain points should be stressed. For dealing with newcomers and tourists, long-term residents have developed postures that tend to be polite but distant. These postures help bring the aesthetic realm into focus; I could observe them easily but, for obvious reasons, did not want to be on the receiving end, which was likely if I behaved too much like a "foreigner" or a "scientist."

Several discussions with men convinced me that scientists were not held in high regard. When I told one man that a friend of mine, an oceanographer, was studying the causes of the meandering of the Gulf Stream along the North Carolina coast, he replied that he already knew the cause: "God made it that way." Another pointed with disdain to a working party from a local university documenting the growing habits of milfoil in Chesapeake Sound with a view to eradicating it. "It'll be here when you and I are long gone" was his main comment. Use of formal methodologies would almost certainly have cast me as a scientist for such people.

Under any circumstances aesthetic contemplation is fragile and can 
be destroyed by questioning of any sort, formal or informal (imagine trying to listen to a favorite piece of music while a stranger fires questions at you about it). Yet once an aesthetic experience is over, it can be difficult to recapture and articulate subjective states. To overcome this dilemma I tried to participate in everyday life as fully as possible without being too obtrusive. I learned the aesthetic components of activities by engaging in them, observing local responses, and asking questions when appropriate. Sometimes I was taught correct aesthetic behavior directly when I was struggling with unfamiliar occupations, such as duck hunting. At other times I noted the aesthetic import of conversations and activities. I tried to tie my questions to current activities and not talk in abstractions and generalizations when away from the relevant activity. Thus I talked about cooking with women as they cooked and about the placement of duck decoys with hunters during hunting sessions.

In the normal course of events clear linguistic cues or other behaviors gave me strong indications of aesthetic experiences. For example, the common local expression "It's all according to what you like" was a signal that what was being discussed was a matter of taste. On one occasion I was quail hunting with a man who knew I had a camera in my pocket. When his dogs froze on point at a covey, he took a long look and said to me, "That's just beautiful, take a picture of it for me." In regular conversation I was never able to elicit from this same man any statements about what he considered beautiful.

A few coincidences of mental states between me and those around me prompted a deep rapport on aesthetic issues. Several of the women in the community occasionally expressed concern about my eating habits, a concern brought on by two distinct factors. First, I have by local standards a slight build $\left(5^{\prime} 10^{\prime \prime}, 120 \mathrm{lbs}\right.$.) and a spare appetite. Second, it took me some time to adjust to the local food. But not eating heartily can be cause for concern on the part of local cooks, who take it as a sign both of sickness and of indifference to their offerings, in which they take great pride. One raw November day, however, a cook prepared haslet stew for me-a watery concoction of pig's heart, liver, and other offal with wheat flour yeast dumplings floating on top. As it happens, my mother had made a similar dish when I was a small boy and I was quite partial to it, but she stopped making it when I was ten years old or so and never made it again despite my occasional nudgings. When the great bowl of stew was put in front of me, I immediately made up a big plateful and wolfed it down, did the same to a second, and made a strong attack on a third, 
to the complete and overt delight of the cook. The incident led to a long discussion about the aesthetics of food and its associations.

Despite my conscious effort to stay away from formal methods, it was convenient, from time to time, to conduct directed interviews on topics that would normally be discussed in conversation. Most of these interviews took place toward the end of my study year, when my position in the community was firmly established and not likely to be jeopardized by such behavior. I also carried out limited experiments that began with requests from people in the community. On two separate occasions people who knew my general project asked me to give slide shows. One woman had me set up my projector in her house and invited a few of her friends over, and a general store owner set up a screen in the store after hours and let it be known to the men who hung around the store that they were welcome to participate. In both cases I selected slides of a variety of objects and events and noted responses. These experiments were useful in that they confirmed my general suspicions, but they were not essential to my general explorations.

What I hope to convey in ensuing chapters, therefore, is a sense of the aesthetic realm of Tidewater in action, as I saw it and participated in it rather than as it was related to me. Although I make no absolute claims as an insider, I have good reason to suppose that my vantage point was generally privileged.

Before launching into data concerning aesthetics, however, I note some basic information about Tidewater and especially about the natural environment (I consider the aesthetic judgments associated with the natural landscape in later chapters). The natural environment is a major component in the lives of all the people who live in Tidewater and a significant factor in generating aesthetic forms. I follow this outline of the natural world with some observations on the relationship between the environment and a few key social facts, in particular the ongoing movement of people in and out of Tidewater.

Tidewater is located on a wide peninsula that runs out into Tidewater Sound. The center of the peninsula is about fifteen feet above sea level and slopes gently down on either side through marsh and swamp to the water. A narrow, sluggish river runs through the town, draining toward the sound in the east. Otherwise the physical landscape is featureless.

There are four broad classes of soil on the peninsula. The central ridge is characterized by high-quality loams. Sloping gradually away from these prime lands, which are very narrow, are broader bands of 
poorer yet cultivable loamy sands and sandy loams. Together these soils form a strip approximately three thousand feet wide. They are moderately to poorly drained, though occasional stretches in the higher elevations are well-drained. The water table is on average fifteen inches below the surface, so that flooding is an intermittent problem. Beyond the cultivable soils lie wide bands of deep, poorly drained, alluvial sediments. Beside them stretching to the water are broad, flat expanses of swamp land soils, typically wet on the surface with a poor topsoil layer.

These soils support five plant communities, roughly divisible into dryland and wetland: agricultural/settled, old field, and mixed mesic forest in the former, cypress swamp and sawgrass marsh in the latter. These communities, like the soils that support them, run in bands of increasing width from the ridge down to the water.

The central corridor of good soils has been cleared of its natural covering and is planted in commercial crops or built on. However, the margins of these cleared areas support remnants of the original mixed mesic covering, such as button bush, sweetgum, blackberry, and honeysuckle, and weedy species such as dandelion, bedstraw, and a variety of grasses. Interspersed in these cleared lands are old fields, used at one time for agriculture but recently allowed to go more or less wild. They are mostly covered with broomsedge, with loblolly pines dotted about. Like the agricultural lands, these cleared fields show remnants of the original mixed mesic growth, particularly on the margins.

On either side of the cleared lands the mixed mesic forest forms a high, dense wall, so that standing on the peninsular ridge one has the impression of being enclosed on both sides by wilderness. Deciduous trees such as oaks, willow, sweetgum, and red maple form the primary tree covering and make a thick canopy in spring and summer. Beneath them grow smaller trees and shrubs-American holly, sweet bay, sourwood, cane, and wax myrtle. The floor is sparely covered by different grasses.

The mixed forest gives way to cypress swamp as the ground gets lower and less well-drained. Between the mesic growth and the cypress swamp proper are narrow strips of swampy lands dominated by red bay, black gum, and pond pine. As the ground water becomes deeper, toward the margin of the sound, the bald cypress becomes the dominant species. The bases of these trees are host to several shrubs, including swamp rose, sweet pepperbush, Virginia tea, and winterberry. Between the river and the swamp are small pockets of sawgrass 
marsh mostly covered in sawgrass, but drier spots support a few mesic shrubs. The river itself supports a small plant community of openwater species: milfoil and Lilaeopsis.

The fauna of the region is rich and diverse. The agricultural land corridor supports the smallest number of species. Crop lands are picked over by white-tailed deer, snow geese, meadowlarks, and mourning doves. Margins, drainage ditches, and brambly hedgerows house small rodents. Old fields have a similar population, with scattered colonies of rabbits and quail and a proportionately higher number of predator species, including the red-tailed hawk and black ratsnake.

The mesic forest lands are inhabited by a great variety of perching and predator birds and a host of land mammals and land reptiles. Small rodents occupy the forest floor, along with lizards, snakes, and toads. White-tailed deer forage and browse, while overhead passerine birds and raptors perch, nest, and feed.

The wetlands teem with wildlife. True amphibians (frogs, toads, and salamanders) share the habitat with amphibious mammals (mink, nutria, and marsh rabbit) and amphibious reptiles (watersnakes and turtles). These lands are also important breeding grounds for such waterfowl as green heron and wood duck, and wintering territory for many species of ducks and geese. Black bear and bobcat are occasionally though rarely sighted, the latter being more often heard than seen.

Beyond the wetlands the open waters of the sound provide spawning ground and territory for both freshwater fish, such as alewife, largemouth bass, perch, shad, carp, and catfish and saltwater types that spend portions of their life cycle in brackish waters, such as spots and croakers. These in turn support fish-eating birds: ducks, gulls, and osprey.

The climate is oceanic, with mild winters and temperate summers. The average temperature in January is $45^{\circ} \mathrm{F}$. and in July is $80^{\circ} \mathrm{F}$. The average rainfall is fifty inches per annum, half of which falls between April and August. The first frost of the year generally comes in midNovember, the last at the beginning of April, giving an average frostfree period of 235 days. Tropical storms and hurricanes are not frequent but create serious flooding problems when they occur. Severe storms generally come out of the northeast and push water back up rivers and creeks flowing toward Chesapeake Sound.

The natural environment of Marsh County has severely restricted housing in Tidewater. Because the whole region is a peninsula, with well-drained soils only along its spine, the potential for growth has 
Figure 1. Kindred, showing patterns of migration
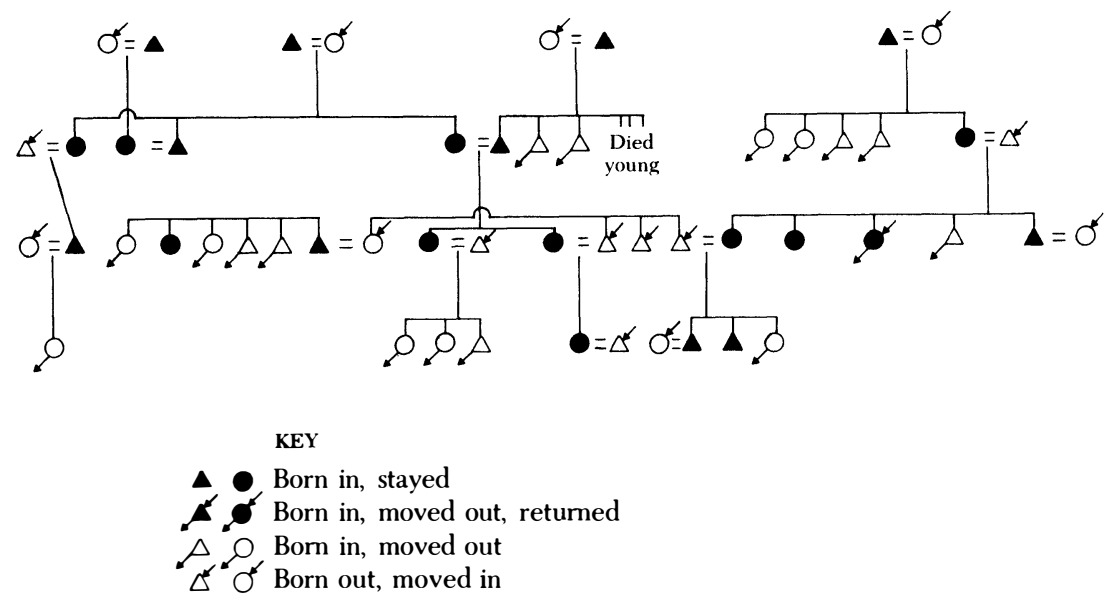

always been limited. From the earliest days a road has run down the spine for access between local communities, but until the 1930s the road did not lead out of the peninsula because deep swamp blocked the way. The oldest houses in Tidewater were built on the road and spaced evenly along it with farmlands beside and behind them; each house commanded ten to twenty acres of prime land. These apparently small plots were primarily for food and supplementary income, because families earned their living at freshwater fishing and market hunting. Even so, the farms were a vital part of the family economy, and a waterman could not live without a smallholding. Once the land had been carved into these small family farm plots, there was little prospect of expansion. New houses could not be built without reducing the area of farmland, and new land for farming was not available because of physical limits set by the marshes.

These chronic limitations on land established a pattern of in- and out-migration to be seen clearly in the movements of a kin group over several generations. Figure 1 shows the movements in and out of all of the members of four generations of related families.

Patterns of movement are roughly similar for men and women, with the numbers moving out slightly higher than those moving in (see Table 1). The net effect was to stabilize the numbers of each family living in the community, the net loss to other communities balancing fertility. In simple terms, one child inherited the "home place" and the rest married outside the community. The child who inherited 
Table 1. Movements of Tidewater men and women

\begin{tabular}{lrcc}
\hline & Men & Women & Total \\
\hline Born in/stayed in & 11 & 10 & 21 \\
Born in/moved out & 8 & 9 & 17 \\
Born out/moved in & 7 & 8 & 15 \\
Totals & 26 & 27 & 53 \\
\hline
\end{tabular}

Source: Data from Figure 1.

married someone from outside the community who had failed to inherit in his or her own community. Table 2 documents the origins of the married couples shown in Figure 1. Of sixteen marriages only two were between a man and a woman both born in Tidewater. The fourteen other marriages are roughly split between local husband and local wife. The outcome of this pattern was a strong identification with the family land and the homestead on it.

In the 1930s, with the development of the technology to build roads through swampland, the local road was linked to the mainland of North Carolina and residence patterns changed significantly. Men who in the past had moved away because family lands could not support them now could commute to jobs in larger towns outside the county. The road also solved the problem of where they would live. Two men who owned substantial farms by the river took outside employment and carved up their lands into building plots. The community became nucleated where these two farms had been, and there was a flurry of building in the 1930s and 1940s.

The new road also brought outsiders into the town. In the 1960s families began moving in from Virginia and from other parts of North Carolina for a variety of reasons. The general cost of living is low, state and local taxes are reasonable, and there are opportunities for water sports of all kinds. The arrival of these outsiders was made possible as

Table 2. Marriages and movements of Tidewater men and women

\begin{tabular}{lc}
\hline Man $\quad$ Woman & Number \\
\hline Born in = Born in & 2 \\
Born in = Born out & 8 \\
Born out = Born in & 6 \\
Total & 16 \\
\hline
\end{tabular}

Source: Data from Figure 1. 
more local families sold building plots or turned farmland into mobile home parks. They did so for a number of reasons, including a general decline in the profitability of small farms and fishing. This pattern of in-migration is fundamentally different from the old one. In the days before the new road system the men and women who moved into the community were from other parts of the county and shared their cultural values with the people of Tidewater. Furthermore they did not simply move in, they married into the community. Modern newcomers are real outsiders. They come from different cultural backgrounds, and they move in as entire family units. The tensions that now exist between newcomers and old families have brought some social structures-the aesthetic in particular-into sharp focus.

For the sake of convenience I have divided my field data on aesthetics into four categories: home, work, church, and leisure. These categories have no special theoretical import and are not entirely discrete entities. In many ways, however, the data fall naturally into these domains, which local people recognize as socially significant. I have tried to present the data from the local perspective as much as possible, though I am mindful of the problems inherent in making such a claim (see Clifford and Marcus 1986). Whenever my own feelings or viewpoint are expressly given, they are clearly marked as such. In general such statements involve preliminary classification and comparison of the data on a very limited scale in order to create a series of analytic threads. For example, I indicate from time to time when aesthetic forms are conspicuously present or absent, when they are natural versus artifactual, when they are highly embellished in contrast to others that are unadorned, when aesthetic values are those of men or of women or both, and so on. I pick up these threads and use them in a more extensive analysis in the concluding chapter. 